\title{
Evaluation of Public Transport Performance Supporting Monorail Planning
}

\author{
Lasmini Ambarwati, and Amelia K. Indriastuti
}

\begin{abstract}
Public transport (PT) performance in some big cities in Indonesia is not accordance with passenger satisfaction. This condition is revealed by investigation of public transport performance declining continually. This condition causes the number of PT's passenger decreasing and increasing in use of private vehicles. Current research is insufficient to evaluate the existing public transport performance in order to improve the service level of PT. Surabaya City has planned improvement of PT system with MRT (monorail) serving passenger in western and eastern regions of the city. The present paper examines standard requirements for PT performance by applying Importance Performance Analysis (IPA) and the probability to choose the monorail system.

The results indicate that headway is important factor to improve the existing PT. Other factors (travel time, availability of PT and load factor) should be considered in the improvement of PT. Monorail system can be planned as alternative transport mode with considering the difference of the attribute between monorail and the current $P T$, i.e. waiting time less than 5 minutes, travel cost 1,000 IDR and travel time less than 12 minutes. The monorail system has a good challenge to solve congestion problem because of matches with passengers' demand and preferences.
\end{abstract}

Index Terms - Improvement of public transport, monorail system, mode choice, passenger satisfaction public transport performance.

\section{INTRODUCTION}

$\mathrm{M}$ inibus (paratransit) is most the existing public transport (PT) mode in Surabaya City. Generally, paratransit serves passenger in order having high mobility in the city of Surabaya as a case study area. The existing public transport is expected accommodating citizen trip demand from origin to destination. Currently, the city of Surabaya has public transport network consisting of minibusses (paratransits) and busses. There are 68 available minibus routes, and 22 bus routes (minibus accommodates $8-12$ passengers, while bus has 50-55 seats). Half of the existing routes serves passenger from western and eastern regions of the city. According to city planner association, Jakarta and Surabaya City have the worst public transport performance [1]. The consequence of this condition is increase of the use of

LAmbarwati is with ${ }^{1}$ Civil Engineering Department, Faculty of Engineering, Brawijaya University, Malang, East Java Province, Indonesia, 65142 (e-mail: labarwati@ub.ac.id).

A.K. Indriastuti is with the Department of Civil Engineering, Diponegoro University, Semarang, Indonesia (e-mail: akindraist@yahoo.com). private vehicles. There is an addition of 12,000 motorcycles and 3,000 cars each month in Surabaya City [2].

In a decade with high investment, Australia has re-emerged light rail as inner-city transit investment. Even though Australian light rail had lower performance compared to its European and North American, Australia focused on improve the effectiveness of light rail and medium-term plans for light rail as a solution for urban access. Some efforts were done by increasing ridership productivity (passengers per vehicle $\mathrm{km}$ ) with tram route 109 and rising ridership effectiveness (11.5 boardings per vehicle $\mathrm{km}$ ). This LRT system is expected to provide reliable and higher capacity in congested inner urban contexts [3].

Insufficient research concerns on evaluating the performance of the existing public transport (PT) in order to support the possibility improvement of PT, such as planning monorail system. Monorail system is expected to increase citizen mobility. Briefly, this study focuses on the assessment of the existing public transport performance and the probability of monorail mode choice in Surabaya City as a case study area.

The remaining paper is organized as follows. Data collection and Importance Performance Analysis (IPA) are explained in Section 2, the following sections describe methods, clarifying significance of variables influencing the existing public transport and some factors should be considered in improvement of public transport as well the factors influencing the probability to choose monorail system. Results and Discussions section explains how to improve the existing public transport based on assessment value of PT performance and probability of choosing monorail system. Finally, conclusions and recommendations are presented.

\section{METHOD}

\subsection{Data collection}

Before an assessment of the existing public transport (PT), it is necessary to collect primary and secondary data. The current performance of public transport such as capacity, quality, and efficiency was measured by conducting an on-board survey for bus and minibus/paratransit. The results of this survey were used as input for assessment of PT performance. Other data was collected by distributing questionnaires related to improvement PT system with establishing monorail system.

Data was investigated informing that each part of the city is served by approximately 26 minibus routes, except the southern part of the city, which is accommodated by 10 
minibus routes. Transport data was collected by using an extensive survey (2013). From the questionnaires distributed, a total of 554 respondents, a representative of residents of 163 desas which have a population of approximately three millions, high density of more than 11,000 persons per $\mathrm{km}^{2}$ [4]. Analysis was based on data collected from all respondents. The questions were divided into four groups: socio-economic background; trip characteristic and transport mode choice; residents' preferences regarding the current performance of public transport, i.e. the operational of PT, factors influencing service level of PT (load factor, headway, travel time, availability of $\mathrm{PT}$, waiting time, cost, route suitability, security and safety); passengers' preferences with planning monorail system. Respondents assess satisfaction level and importance level to the factors influencing operational of the current PT in five scales (not very important, not important, doubting, important, and very important). Another set of questionnaire was distributed to some respondents in the study area using stated preference approach.

The public transport performance consists: a). load factor, by determining the numbers of loaded passengers and unloaded at one terminal to another terminal, b). headway, by understanding the different time of departure and arrival in one point along the route (minutes), c). speed and routes length, d). travel time, by computing time to travel for PT from one terminal to other terminal, e) availability of PT, f) waiting time, g) route suitability, and h) safety.

First purpose is assessment of the current public transport performance by employing Important Performance Analysis (IPA). The second purpose is identification of the mode choice trend (among taxi, motorcycle, car, and paratransit) with respondents' socio-economic background, trip characteristics and transport mode characteristics using the logistic linear model. Binary logic model is used to analysis of choosing transportation modes. Using non-linear equation, this model draws the probability of transportation mode choice as a function of the utility. Furthermore, for the second purpose, an analysis on the altering mode choice from current public transit to monorail system is required. The analysis is based on the improvement of the public transport (PT) by planning monorail system. Using stated preference approach, the respondents were asked about their willingness to shift transport mode choice, from the existing public transit (paratransit) to monorail system.

\subsection{Important Performance Analysis (IPA)}

Assessment of the current public transport performance is done by IPA (Important Performance Analysis). IPA combines a measure of attribute importance and performance into a two-dimensional grid to ease the data interpretation. The three-steps of IPA analysis are as follows:

a. Determine the scale of importance using Likert scale which has 5 scales (5:very important, 4:important, 3:doubting, 2: not important, 1: not very important);

b. Set the appropriate level.

Passengers were asked about how they asses the quality and the importance of the current public transport. Several factors were assessed such as load factor, headway, travel time, availability of PT, waiting time, cost, route suitability, security and safety. Appropriate level will be analyzed by the following equation.

$T_{k i}=\frac{X_{i}}{Y_{i}} \times 100 \%$

where $T_{k i}$ is the appropriate level, $X i$ is the score of perception and $Y i$ is the importance score

c. Determine the quality of level of service $(X)$ and importance score $(Y)$ using Cartesian diagram as seen in Fig.1. The quality of service $(X)$ and the importance score are determined as the average values over $n$ number of respondents and represented as $\bar{X}$ and $\bar{Y}$, respectively.

$\overline{\bar{X}}=\frac{\sum_{i=1}^{n} \overline{X_{i}}}{k} \quad$ and $\quad \bar{Y}=\frac{\sum_{i=1}^{n} \overline{Y_{i}}}{k}$

where $k$ is the number of attribute assessed.

d. Determine $\overline{\bar{X}}$ and $\overline{\bar{Y}}$ in Cartesian diagram as the Importance-Performance Grid to verify each quadrant. The mean of each quadrant in Cartesian diagram is as follows:

1) Quadrant A has high importance but low quality of the service so that, it can be considered as "concentrate here"

2) Quadrant B has high level for both importance and level of service so that, it has a category of "keep up the good work"

3) Quadrant C has a category of "low priority" as this quadrant has low level for both importance and level of service

4) Quadrant D is the opposite of quadrant A, that is, it has high level of service but low importance level so that, it is considered as "possible overkill" [5].

The importance-performance analysis (IPA) is a widely used analytical technique that yields references for evaluation of infrastructure and management according to respondent satisfaction. IPA is a two-dimensional grid based on customerperceived importance of quality attributes and attribute performance. Depending on the interplay of these two dimensions, strategies for satisfaction management can be determined. IPA has been applied to evaluate customer satisfaction with a supplier in the automotive industry [6]. 


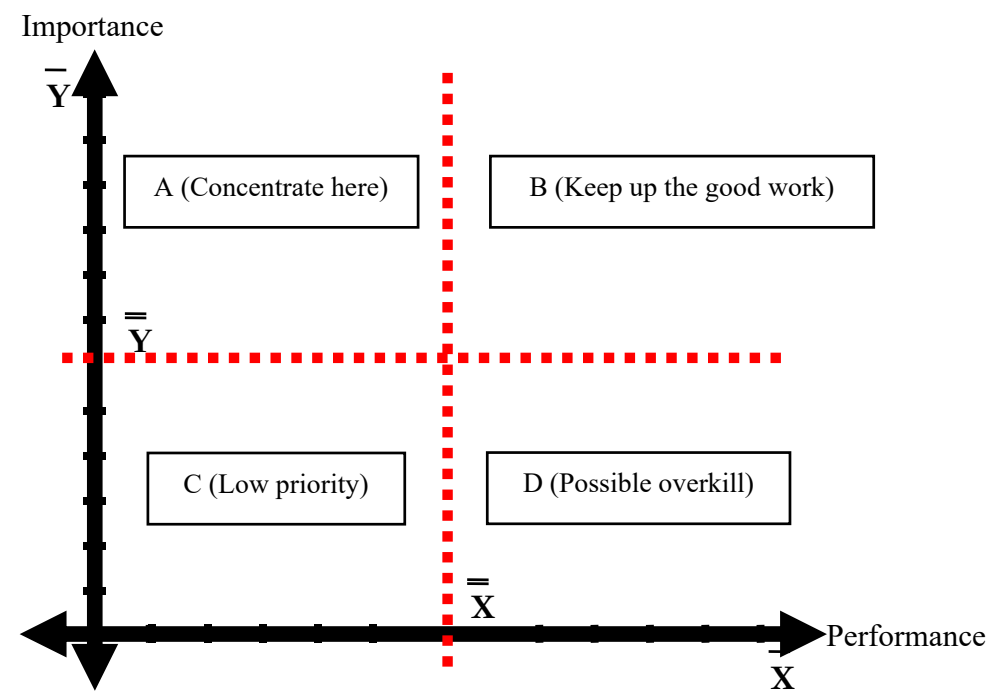

Fig. 1. Cartesian Diagram in IPA

\section{RESULTS AND DISCUSSION}

\subsection{Evaluation of Operational Performance of Current Public Transport}

Several routes of the existing public transport were observed in order to evaluate and to compare with the performance standard according to Transportation Department [7- 9].
From Table 1, it is shown that headway of Dukuh KupangOsowilangun route is more than standard. It means that the number of mode is less than demand. The current public transport (PT) has small load factor that it means passenger do not interest to use the existing PT. This situation has an effect in longer travel time approaching 1.5 hours (peak hour) and 2 hours (off-peak hour). Another route, Perak-Benowo route also has headway more than standard meaning small number of the current PT operated.

TABLE I

\begin{tabular}{|c|c|c|c|c|c|}
\hline \multirow{2}{*}{ Route } & \multirow{2}{*}{ Indicators } & \multirow{2}{*}{ time } & \multicolumn{2}{|c|}{ Comparison } & \multirow{2}{*}{ Note } \\
\hline & & & $\begin{array}{c}\text { Current } \\
\text { performance }\end{array}$ & Standard & \\
\hline \multirow[t]{6}{*}{$\begin{array}{l}\text { Joyoboyo- } \\
\text { Lakarsantri }\end{array}$} & Headway & Peak hour & $\begin{array}{l}2.6-3.2 \\
\text { minutes }\end{array}$ & $2-5$ minutes & According to standard \\
\hline & & Off-peak hour & 3-3.3 minutes & 5-10 minutes & According to standard \\
\hline & Load factor & Peak hour & $17.4-30.3 \%$ & $70 \%$ & According to standard \\
\hline & & Off-peak hour & $18-23.4 \%$ & & According to standard \\
\hline & Travel time & Peak hour & $\begin{array}{c}0.73-0.77 \\
\text { hours }\end{array}$ & $1-1.5$ hours & According to standard \\
\hline & & Off-peak hour & $\begin{array}{c}0.73-0.81 \\
\text { hours }\end{array}$ & 2-3 hours & According to standard \\
\hline \multirow{7}{*}{$\begin{array}{c}\text { Dukuh } \\
\text { Kupang- } \\
\text { Osowilangun }\end{array}$} & Headway & Peak hour & 7.4-17 & $2-5$ minutes & More than standard \\
\hline & & Off-peak hour & $14.9-15.9$ & 5-10 minutes & More than standard \\
\hline & & & minutes & & \\
\hline & Load factor & Peak hour & $23.4-36.5 \%$ & $70 \%$ & According to standard \\
\hline & & Off-peak hour & $22-27.2 \%$ & & According to standard \\
\hline & Travel time & Peak hour & $1.2-1.45$ & $1-1.5$ hours & According to standard \\
\hline & & Off-peak hour & $1.48-1.49$ & $2-3$ hours & According to standard \\
\hline \multirow[t]{6}{*}{ Perak-Benowo } & Headway & Peak hour & $3.2-5.8$ & $2-5$ minutes & More than standard \\
\hline & & Off-peak hour & $6.8-8.1$ & 5-10 minutes & According to standard \\
\hline & Load factor & Peak hour & $22.6-38.4$ & $70 \%$ & According to standard \\
\hline & & Off-peak hour & $25.7-28.3$ & & According to standard \\
\hline & Travel time & Peak hour & $1.0-1.37$ & $1-1.5$ hours & According to standard \\
\hline & & Off-peak hour & $1.25-1.3$ & $2-3$ hours & According to standard \\
\hline \multirow{6}{*}{$\begin{array}{l}\text { Joyoboyo- } \\
\text { Manukan }\end{array}$} & Headway & Peak hour & $4.7-5$ & $2-5$ minutes & According to standard \\
\hline & & Off-peak hour & $5.8-6$ & 5-10 minutes & According to standard \\
\hline & Load factor & Peak hour & $40.8-58 \%$ & $70 \%$ & According to standard \\
\hline & & Off-peak hour & $27-53.2 \%$ & & According to standard \\
\hline & Travel time & Peak hour & $0.7-1$ & $1-1.5$ hours & According to standard \\
\hline & & Off-peak hour & $0.76-0.93$ & $2-3$ hours & According to standard \\
\hline
\end{tabular}




\subsection{Analysis of PT performance}

Passengers' perception is conducted to assess factors influencing service level of PT, i.e. load factor, headway, travel time, availability of PT, waiting time, cost, route suitability, security and safety. Passengers were asked to evaluate importance level and satisfaction level to the existing public transport performance. Table 2 informs factors considered to evaluate the performance of current public transport.

TABLE II

PERFoRMANCE OF THE EXISTING PUBlic TRANSPORT

\begin{tabular}{|c|c|c|c|c|}
\hline Route & $\begin{array}{c}\text { Quadrant } \\
\text { A }\end{array}$ & $\begin{array}{c}\text { Quadrant } \\
\text { B } \\
\end{array}$ & $\begin{array}{c}\text { Quadrant } \\
\text { C }\end{array}$ & $\begin{array}{c}\text { Quadrant } \\
\text { D }\end{array}$ \\
\hline $\begin{array}{l}\text { Joyoboyo- } \\
\text { Lakarsantri }\end{array}$ & 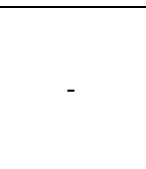 & $\begin{array}{l}\text { Security, } \\
\text { safety }\end{array}$ & $\begin{array}{c}\text { Headway, } \\
\text { travel } \\
\text { time, } \\
\text { waiting } \\
\text { time }\end{array}$ & $\begin{array}{c}\text { Load factor, } \\
\text { availability } \\
\text { of PT, cost, } \\
\text { route } \\
\text { suitability }\end{array}$ \\
\hline $\begin{array}{l}\text { Dukuh } \\
\text { Kupang- } \\
\text { Osowilangun }\end{array}$ & $\begin{array}{c}\text { Travel } \\
\text { time, } \\
\text { availability } \\
\text { of PT }\end{array}$ & $\begin{array}{l}\text { Security, } \\
\text { safety }\end{array}$ & $\begin{array}{c}\text { Load } \\
\text { factor, } \\
\text { headway, } \\
\text { waiting } \\
\text { time }\end{array}$ & $\begin{array}{l}\text { cost, route } \\
\text { suitability }\end{array}$ \\
\hline $\begin{array}{l}\text { Perak- } \\
\text { Benowo }\end{array}$ & $\begin{array}{l}\text { Load } \\
\text { factor, } \\
\text { Security, } \\
\text { safety }\end{array}$ & - & $\begin{array}{l}\text { Travel } \\
\text { time, } \\
\text { waiting } \\
\text { time, } \\
\text { route } \\
\text { suitability }\end{array}$ & $\begin{array}{l}\text { Headway, } \\
\text { availability } \\
\text { of PT, cost }\end{array}$ \\
\hline $\begin{array}{l}\text { Joyoboyo- } \\
\text { Manukan }\end{array}$ & Travel time & $\begin{array}{l}\text { Load factor, } \\
\text { Security, } \\
\text { safety }\end{array}$ & $\begin{array}{l}\text { Headway, } \\
\text { waiting } \\
\text { time, } \\
\text { route } \\
\text { suitability }\end{array}$ & $\begin{array}{l}\text { availability } \\
\text { of PT, cost, }\end{array}$ \\
\hline
\end{tabular}

Table 2 explains what factors should be considered as major factors in improvement of current public transport (Quadrant A), i.e. travel time, availability of PT, load factor. Other factors in Quadrant B should be maintained to evaluate performance of the existing PT. Security and safety are factors expected in considering performance of the existing PT because the number of accident increases with involvement of PT and some crimes occur in the PT. Quadrant C shows factors that are not important for passengers such as headway and waiting time. Other factors consist of cost, route suitability are not importance for passengers.

Improvement of current public transport needs to evaluate travel time, availability of PT and load factor in order to improve the PT performance. These factors are improved appropriate with passengers' preferences.

\subsection{Probability for choosing monorail system}

Based on analysis of current PT by employing IPA, travel time is expected increase by improving PT system such as planning of monorail system. Other factors are waiting time and travel cost based on previous studies. Using stated preference method, the factors influencing passengers' willingness to shift transport mode choice, from the existing public transit (para-transit) to monorail system were asked. These factors will be assessed according to passengers' preference by analyzing questionnaires distributed to them. Data is analyzed by binomial logic model using three variables (travel time $\left(\mathrm{X}_{1}\right)$, waiting time $\left(\mathrm{X}_{2}\right)$ and travel cost $\left(\mathrm{X}_{3}\right)$ ).

From data, travel length is measured approximately 15.13 $\mathrm{km}$ for all parts of the city of Surabaya, travel time is about 60 minutes to take a trip from a part region of Surabaya city to the city center. Travel cost is assumed 5,000 IDR according to ticket price. Waiting time is assumed 10 minutes to get public transport.

\section{A. Travel time variable.}

Based on analysis of binary logic model, the utility function with difference of travel time and the probability of choosing monorail and the existing public transport (PT) can be formulated as follows:

$$
\begin{gathered}
U_{\text {monorail }}-U_{P T}=0,400-0,033 \Delta X_{1} \\
P_{\text {monorail }}=\frac{\mathrm{e}^{0,400-0,033 \Delta \mathrm{X} 1}}{1+\mathrm{e}^{0,400-0,033 \Delta \mathrm{X} 1}} \\
P_{P T}=1-P_{\text {monorail }}
\end{gathered}
$$

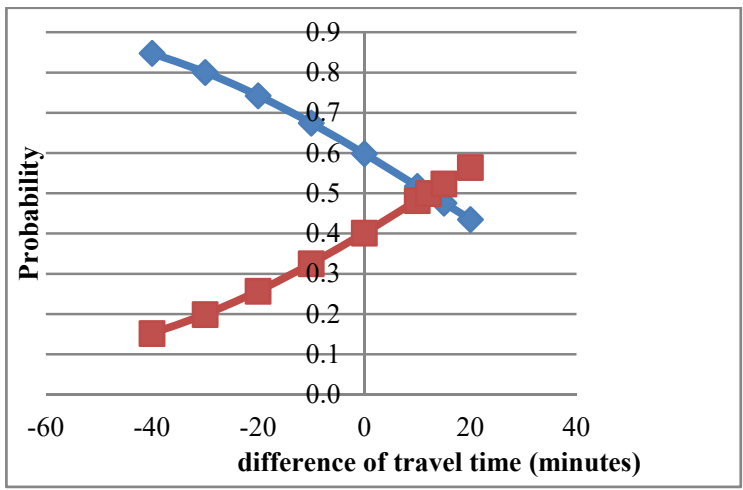

Fig. 2. Mode choice model based on travel time variable Note: blue shows probability to choose monorail whereas red informs probability to select the existing PT.

Fig. 2 explains the change of travel time between monorail and public transport (PT). Passenger tends to choose monorail within difference of travel time approximately 0-12.12 minutes. It means that monorail system is expected having higher speed than the existing PT as consequence in decreasing travel time up to 12.12 minutes. This result is in line with the fact that consumers prefer to choose flexible transportation mode with minimum travel time.

\section{B. Travel cost}

Travel cost attribute has an effect on utility function for mode choice, as follows:

$$
U_{\text {monorail }}-U_{P T}=0,630-0,715 \Delta X_{2}
$$

Probability for choosing monorail system is explained:

$$
P_{\text {monorail }}=\frac{\mathrm{e}^{0,630-0,715 \Delta \mathrm{X} 2}}{1+\mathrm{e}^{0,630-0,715 \Delta \mathrm{X} 2}}
$$




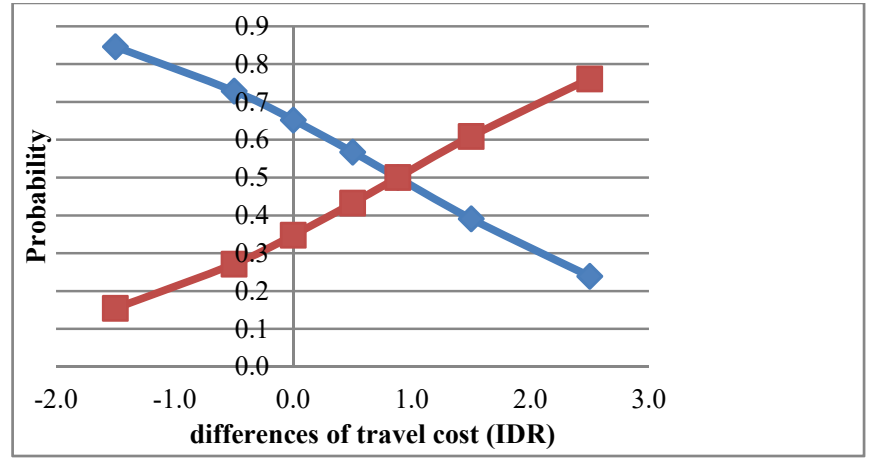

Fig. 3. Probability for mode choicel based on travel cost variable Note : blue shows probability to choose monorail whereas red informs probability to choose the existing PT.

Fig. 3 informs the probability of choosing monorail and the existing PT based on travel cost variable. Passenger will choose monorail with differences of travel cost minimal 1,000 IDR. It means that government should be subsidized monorail ticket up to passenger ability to pay monorail ticket.

\section{Waiting time variable}

The utility function and probability to choose monorail system based on wating time variable can be explained :

$$
\begin{gathered}
U_{\text {monorail }}-U_{P T}=0,743-0,148 \Delta X_{3} \\
P_{M R}=\frac{\mathrm{e}^{0,743-0,148 \Delta \mathrm{X} 3}}{1+\mathrm{e}^{0,743-0,148 \Delta \mathrm{X} 3}}
\end{gathered}
$$

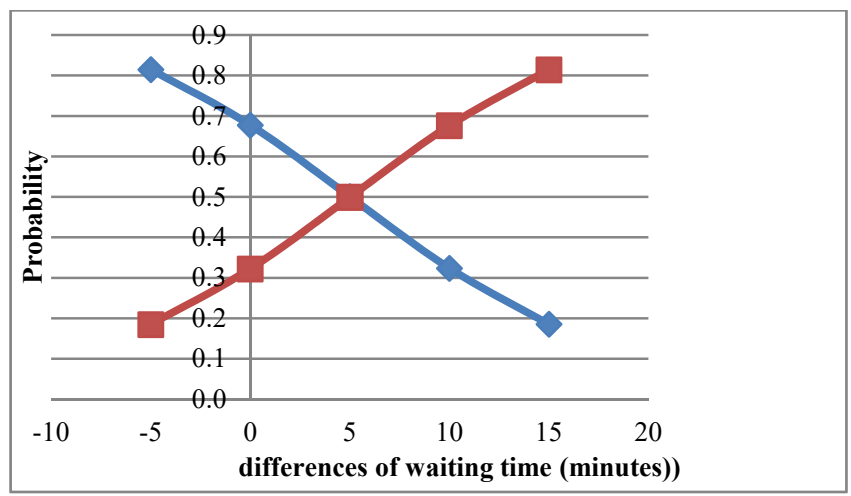

Fig. 4. Probability for mode choice based on waiting time variable Note : blue shows probability to choose monorail whereas red informs probability to choose the existing PT.

Illustration of differences of waiting time between monorail and the existing PT is explained in Fig. 4. With differences of waiting time less than 5 minutes, passenger prefers to use monorail system. It means that monorail system should have headway less than 5 minutes which is according to passenger's preference.

\subsection{Passengers’ Characteristics}

By descriptive analysis, passengers characteristics can be explained based on stated preference survey. Passenger preferences support establishing monorail system in Surabaya City. Passenger responds approximately $93.5 \%$ agree to monorail operation. They expect that monorail system can be a solution for the improvement of public transport and for reducing traffic congestion. This result is supported by previous research informing monorail system can be as challenges to shift passengers from private vehicles up to $33 \%$ [10].

From survey, respondents are in 26-35 years (32.5\%) meaning that passengers can pay monorail ticket and have a trip independently. They have background education graduating high school $(50.65 \%)$. With this background education, it is important for monorail management to inform the detail of monorail system operation because of giving easiness for passengers to understand it. They have income less than 1.5 million IDR. This information is used to decide monorail ticket related to respondents' ability to pay. According to respondents, monorail ticket should be approximately $8,000-9,000$ IDR meaning a lot of subsidies to support operation of monorail system.

Passenger demand is clarified that most passengers are workers from private companies $(56 \%)$ who need trip in the morning and evening peak hour. This situation should be arranged by managing less headway on peak hour in order to reduce queuing at stations. It means that monorail routes should pass residential areas and monorail stations are near to their home areas and work places. Respondents (40\%) prefer travel time less than 30 minutes by using monorail system.

For operating monorail system, it is necessary to consider cheap ticket price, safety and comfort, and short travel time which is explained by $47 \%, 71 \%$ and $50 \%$ of respondents respectively informing these aspects considered in monorail operation.

\section{ANALYSIS AND DISCUSSION}

1. The performance of current public transport shows that Dukuh Kupang-Osowilangun route has headway more than standard, small load factor and longer travel time approaching 1.5 hours (off-peak hour) and 2 hours (offpeak hour). Travel time, availability of PT, load factor should be considered as major factors in improvement of current public transport (Quadrant A), Other factors, security and safety in Quadrant B should be maintained to evaluate performance of the existing PT. Quadrant C shows factors that are not important for passengers such as headway and waiting time. Other factors consist of cost, route suitability are not important for passengers.

2. By using stated preference survey, the utility function and probability to choose monorail system can be defined based on variables, i.e. travel time, travel cost and waiting time. By considering difference of these factors between monorail and the current PT, passenger tends to choose monorail within difference of travel time approximately 0 15 minutes, travel cost minimal 1,000 IDR and waiting time less than 5 minutes respectively.

Probability choice model between monorail system and current public transport can be set as reference to operating the monorail system. The results of the study can be 
recommended for further studies in predicting the potency of passengers demand, ticket price, station locations, etc.

\section{REFERENCES}

[1] Bernardus, "Public transport condition in Jakarta and Surabaya (in Indonesian)," 2011.

https://finance.detik.com/properti/d-1647902/angkutan-umum-kotajakarta-dan-surabaya-paling-buruk

[2] Police Department of Surabaya City, "Vehicles growth report for Surabaya City in 2011 (in Indonesian)," Technical Report, Surabaya, Indonesia, 2012.

[3] C. Graham V., and M. Burke, M., "Light rail in Australia-Performance and prospects," Australasian Transport Research Forum 2013 Proceedings 2 - 4 October 2013, Brisbane, Australia, 2013.

Publication website: http://www.patrec.org/atrf.aspx

[4] Statistic Bureau of Surabaya City, "Surabaya City in Figures (in Indonesian)," Technical Report. Surabaya, Indonesia, 2012.

[5] J.A. Martilla, and J.C. James, "Importance-performance analysis," The journal of marketing, pp.77-79, 1977.

[6] K. Matzler, F. Bailom, H.H. Hinterhuber, B. Renzl, and J. Pichler, "The asymmetric relationship between attribute-level performance and overall customer satisfaction: a reconsideration of the importance-performance analysis," Industrial marketing management, 33(4), pp.271-277, 2004.

[7] Directorate General of Land Transportation, "Guidelines for Data Collection of Urban Public Transport," Jakarta: Department of Transportation (in Indonesian), 2001.

[8] Directorate General of Land Transportation, "Technical Guidelines for Implementing Passenger Public Transport in Urban Areas with Permanent and Regular Routes," Jakarta: Department of Transportation (in Indonesian), 2002.

[9] Ministry of Transportation, "Implementation for Distributing People on Roads with Public Transport," Jakarta: Ministry of Transportation (in Indonesian), 2003.

[10] L. Ambarwati, R. Verhaeghe, A.J. Pel, and B. van Arem, "The influence of integrated space-transport development strategies on air pollution in urban areas," Transp. Res. D Trans. Environ. 44, 134-146, 2016. 